\title{
Uji Aktivitas Antimikroba Kombucha Teh Hitam dan Kombucha Teh Kulit Manggis Berdasarkan Lama Fermentasi
}

\section{Antimicrobial Activity Assay of Kombucha Black Tea and Kombucha Mangosteen Peel Tea Based on Fermentation Length}

\author{
Asri S*, Martina A
}

Fakultas Matematika dan Ilmu Pengetahuan Alam, Universitas Riau, Pekanbaru, 28293, Indonesia. Email:

Asri S, Martina A. 2018 - Uji Aktivitas Antimikroba Kombucha Teh Hitam dan Kombucha

Teh Kulit Manggis Berdasarkan Lama Fermentasi. Jurnal Mikologi Indonesia 2 (2), 67-76

\begin{abstract}
Abstrak
Kombucha merupakan minuman hasil fermentasi dengan bantuan simbiosis antara bakteri dan beberapa jenis khamir yang memiliki manfaat sebagai antimikrob. Substrat umum kombucha adalah teh hitam yang mengandung polifenol dan memiliki efek antimikrob. Tanaman dan ramuan herbal lain dapat digunakan sebagai substrat kombucha salah satunya kulit manggis. Penelitian ini bertujuan untuk menentukan waktu optimal pada fermentasi kombucha teh hitam dan kombucha teh kulit manggis dalam menghambat pertumbuhan Staphylococcus epidermidis, Salmonella typhi, dan Microsporum canis. Metode penelitian ini menggunakan Rancangan Acak Lengkap (RAL). Uji aktivitas antimikrob kombucha dengan metode sumuran. Hasil penelitian menunjukkan semakin lama waktu fermentasi maka nilai $\mathrm{pH}$ akan semakin menurun dan zona hambat yang terbentuk akan semakin besar. Zona hambat kombucha teh hitam dan kombucha teh kulit manggis dengan lama fermentasi 14 hari berbeda nyata dan merupakan fermentasi yang optimal serta memiliki potensi kategori daya hambat kuat. Zona hambat paling besar terhadap S. epidermidis dihasilkan pada kombucha teh kulit manggis fermentasi 14 hari dengan luas zona hambat 14,84 mm dibandingkan $S$. typhi dengan luas zona hambat $13,81 \mathrm{~mm}$. Kombucha teh hitam dan kombucha teh kulit manggis berpotensi menghambat pertumbuhan $S$. epidermidis dan $S$. typhi namun tidak mampu menghambat pertumbuhan M. canis.
\end{abstract}

Kata kunci - antimikrob - kombucha - mikrob patogen - waktu fermentasi

\section{Abstract}

Kombucha is a fermented beverage of black tea with a symbiosis culture of acetic acid bacteria and yeasts that have the benefits as antimicrobial. Other herbal ingredients can be used as kombucha substrate one of them mangosteen peel. The aims of this study was to determine incubation time of black tea and of mangosteen peel kombucha tea which is optimal in inhibiting the growth of Staphylococcus epidermidis, Salmonella typhi, and Microsporum canis. This research method uses Completely Randomized Design (RAL). The 
kombucha antimicrobial activities were investigated using well method. The results showed that the longer fermentation time the $\mathrm{pH}$ will decrease and the inhibition zone will be greater. Antimicrobial activities of black tea and a mangosteen peeled kombuch tea in 14 days fermentationis an optimal fermentation time which has strong inhibitory category. The greatest inhibitory zone of S.epidermidis was produced on kombucha 14 day fermented mangosteen peeled tea $(14.84 \mathrm{~mm})$ compared to S.thypi $(13,81 \mathrm{~mm})$. Kombucha black tea and kombucha mangosteen peel tea potentially inhibits the growth of S.epidermidis and S.typhii but unable to inhibit the growth of M.canis.

Key words - antimicrobial - kombucha - microbial pathogen - fermentation length

\section{Pendahuluan}

Peranan obat-obatan tradisional tidak mampu tergeser begitu saja karena kemajuan ilmu pengetahuan dan teknologi modern. Hal ini terbukti dari banyaknya peminat minuman tradisional karena dipercaya berkhasiat bagi kesehatan sebagai pengobatan. Pemanfaatan teh sebagai obat-obatan tradisional sudah lama dilakukan karena memberikan banyak manfaat. Olosunde et al. (2012) menyatakan teh mengandung polifenol yang memiliki efek antimikrob. Infeksi dan resistensi terhadap agen antimikrob menjadi masalah dalam dunia kesehatan hingga saat ini. Penggunaan obat tradisional menjadi salah satu cara untuk mengobati infeksi dan masalah resistensi mikrob terhadap antibiotik (Darmadi 2008).

Kombucha merupakan minuman hasil fermentasi dengan bantuan simbiosis antara bakteri dan beberapa jenis khamir yang memiliki manfaat untuk kesehatan (Pourjafar et al. 2016). Beberapa manfaat kesehatan dari kombucha diantaranya sebagai antimikrob, antioksidan dan dapat mencegah kanker (Jayabalan et al. 2011). Jenis mikrob yang berperan dalam fermentasi kombucha yaitu bakteri Acetobacter xylinum, A.xylinoides, A. aceti, A. pasteurianus, A. nitrogenifigens, Bacterium gluconicum, dan Gluconacetobacter sp. Spesies khamir yang berperan yaitu Brettanomyces bruxellensis, B. lambicus, B. custersii, Candida spp., Kloeckera apiculata, Saccharomycodes ludwigii, S. cerevisiae, Schizosaccharomyces pombe, Zygosaccharomyces bailii dan Pichia spp. (Jayabalan et al. 2014).

Medium umum untuk pertumbuhan kombucha adalah teh hitam atau teh hijau dengan penambahan sukrosa (Loncar 2007). Jiang et al. (2017) menyatakan bahwa tanaman dan ramuan herbal dapat digunakan sebagai substrat pertumbuhan kombucha salah satunya kulit manggis. Fermentasi kombucha menghasilkan berbagai jenis asam organik, vitamin, polifenol, asam amino, dan antibiotik. Ansari et al. (2017) kandungan antibakteri pada minuman kombucha mampu menghambat pertumbuhan Staphylococcus aureus. Lama fermentasi kombucha mempengaruhi kualitas fisik, kimia dan organoleptik kombucha (Ngan et al. 2014).

Staphylococcus epidermidis dapat menjadi agen penyebab infeksi yang semakin sulit diatasi karena resistensi terhadap berbagai agen antimikrobial (Jawetz et al. 1995). Salmonella typhimurium merupakan bakteri patogen pada binatang dan merupakan sumber infeksi bagi manusia yang dapat menyebabkan penyakit tifus (Joseph et al. 2012). Microsporum canis merupakan salah satu jenis jamur yang dapat menyerang jaringan keratinase kulit kepala manusia dan menyebabkan infeksi yang dikenal sebagai dermatophytosis (Mikaeili et al. 2016). Amir et al. (2006) menyatakan bahwa M. canis dianggap sebagai salah satu jenis jamur penyebab infeksi ketombe pada manusia di berbagai negara termasuk Indonesia.

Pencegahan untuk mengantisipasi terhadap infeksi yang disebabkan oleh mikrob patogen perlu dilakukan. Salah satunya menggunakan bahan herbal yang dapat bersifat antimikrob seperti fermentasi kombucha teh hitam dan kombucha teh kulit manggis. Berdasarkan kemampuan kombucha tersebut, sehingga perlu diteliti bagaimana daya hambat 
antimikrob kombucha dalam media teh hitam dan kombucha teh kulit manggis berdasarkan lama fermentasi terhadap S. epidermidis, S. typhi, dan terhadap jamur penyebab ketombe yaitu M. canis.

\section{Metode Penelitian}

\section{Isolasi dan identifikasi jamur dermatofit}

Sampe kulit kepala diambil pada bagian kulit kepala dan rambut yang diindikasi terinfeksi ketombe. Sampel kulit kepala penderita ketombe dikerik dengan spatula kemudian ditampung dalam cawan petri kosong yang steril.Sampel berupa rambut rontok dan kulit kepala yang terinfeksi ketombe diletakkan di atas permukaan medium Sabouraud Dextrose Agar (SDA). Kultur diinkubasi selama 3 minggu pada suhu ruang. Koloni yang telah bersporulasi dicirikan dengan permukaan berbentuk serbuk diambil menggunakan ose steril kemudian disubkultur ke medium yang baru. Kultur jamur diinokulasikan sebanyak satu ose pada medium SDA secara aseptik, kemudian diinkubasikan selama 7 hari. Koloni murni jamur yang telah bersporulasi diambil miseliumnya, kemudian diletakkan diatas kaca preparat. Sampel ditetesi larutan laktofenol dan diamati morfologi jamur diamati secara mikroskopis dibawah mikroskop kemudian diidentifikasi dengan mengacu pada buku acuan Medically Important Fungi (Larone 2002).

\section{Peremajaan dan fermentasi kultur kombucha}

Peremajaan kombucha dilakukan dengan cara yaitu sukrosa sebanyak $20 \mathrm{~g}$ dilarutkan dalam akuades sebanyak $300 \mathrm{~mL}$ dipanaskan hingga mendidih. Teh ditambahkan sebanyak $10 \mathrm{~g}$ dibiarkan hingga teh larut kemudian disaring menggunakan kertas saring steril dan didinginkan hingga suhu ruang (Battikh et al. 2012). Larutan dipindahkan ke dalam botol kaca steril yang telah berisi $30 \mathrm{~mL}$ starter kombucha. Jamur kombucha diletakkan diatas alumunium foil steril kemudian ditimbang sebanyak $10 \mathrm{~g}$ dan diinokulasikan ke dalam botol kaca. Wadah ditutup dengan kain kasa steril diikat dan diinkubasi dalam suhu ruang selama 7 sampai 14 hari. Hasil fermentasi disaring dengan membran filter ukuran 0,45 $\mu \mathrm{m}$ (Yuniarto et al. 2016).

\section{Pengukuran pH}

Pengukuran $\mathrm{pH}$ dilakukan pada hari ke 0-14. Uji keasaman dilakukan dengan cara $\mathrm{pH}$ meter yang dicelupkan ke dalam $50 \mathrm{~mL}$ masing-masing larutan kombucha teh hitam dan kombucha teh kulit manggis.

\section{Uji aktivitas antimikrob kombucha dengan metode sumuran}

Uji daya hambat menggunakan metode sumuran dilakukan mengacu pada Perez et al. (2007) dalam Gandotra et al. (2017). Untuk uji antibakteri, medium Nutrient Agar (NA) diinokulasikan dengan isolat uji sebanyak $10^{6} \mathrm{CFU} / \mathrm{mL}$ dan dituang dengan metode cawan tuang kemudian dihomogenkan dan dibiarkan memadat. Permukaan medium agar kemudian dibuat lubang dengan cork borer berdiameter $5 \mathrm{~mm}$. Lubang sumuran diisi dengan larutan supernatan kombucha sebanyak $50 \mu \mathrm{L}$ dengan perlakuan fermentasi 0, 7 dan 14 hari. Kontrol positif diisi dengan kloramfenikol dan amoksilin sebanyak $50 \mu \mathrm{L}$. Kontrol negatif diisi dengan larutan teh hitam dan teh kulit manggis tanpa tambahan kombucha sebanyak $50 \mu \mathrm{L}$. Kultur kemudian diinkubasi dengan suhu ruang selama 24-72 jam. Setelah waktu inkubasi dilakukan pengukuran zona hambat yang terbentuk dengan menggunakan jangka sorong.

Sedangkan untuk uji antijamur, isolat uji sebanyak $10^{6} \mathrm{CFU} / \mathrm{mL}$ diinokulasikan ke dalam medium SDA dengan metode cawan tuang. Permukaan medium dibuat lubang dengan cork borer berdiameter $5 \mathrm{~mm}$. Larutan supernatan sebanyak $50 \mu \mathrm{L}$ dengan perlakuan fermentasi 0, 7 dan 14 hari dituangkan ke dalam lubang sumuran. Kontrol positif lubang 
sumuran diisi sebanyak $50 \mu \mathrm{L}$ dengan miconazol. Kontrol negatif diisi dengan larutan teh hitam dan teh kulit manggis tanpa tambahan kombucha sebanyak $50 \mu \mathrm{L}$. Inkubasi kultur dilakukan pada kondisi suhu ruang selama 24-120 jam. Pengukuran zona hambat yang terbentuk setelah inkubasi dilakukan menggunakan jangka sorong.

\section{Analisis data}

Data yang diperoleh dari hasil isolasi jamur dianalisis secara deskriptif dan ditampilkan dalam bentuk gambar. Data yang diperoleh dari hasil pemeriksaan terbentuknya zona hambat dan uji pH akan dianalisis menggunakan Analysis of Variance (ANOVA) dan dilanjutkan dengan uji Duncan's Multiple Range Test (DMRT) taraf $5 \%$ menggunakan aplikasi software SPSS versi 15.

\section{HASIL}

\section{Isolasi dan identifikasi jamur dermatofit}

Satu jenis jamur dermatofit berhasil diidentifikasi dari rambut penderita ketombe. Hasil identifikasi didapatkan bahwa karakter mikroskopis jamur ini memiliki hifa hialin, mikrokonidia dan makrokonidia. Mikrokonidia memiliki ciri berbentuk bulat seperti anggur berukuran 2-5 x 1-2 $\mu \mathrm{m}$. Makrokonidia memiliki ciri dengan bentuk kumparan, berdinding tebal dan permukaannya kasar, berbentuk spindle shaped dan kedua ujung terlihat runcing serta memiliki sekat 3-7 kompartemen. Makrokonidia berukuran 10-20 x 4-6 $\mu$. Karakter mikroskopis M. canis dapat dilihat pada Gambar 1.

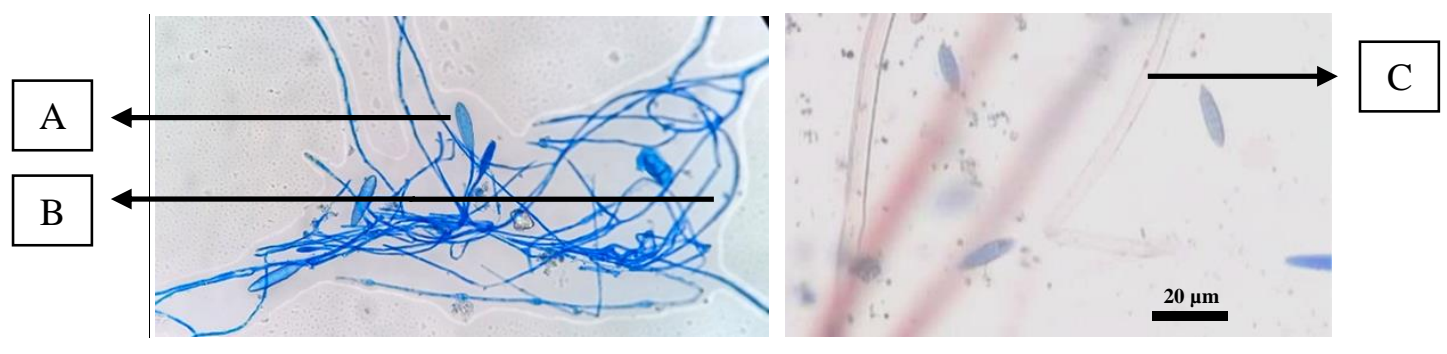

Gambar 1 Microsporum canis perbesaran 40x (A) Makrokonidia berbentuk spindle shaped (B) Mikrokonidia berbentuk bulat dan (C) Hifa hialin

Secara makroskopis isolat yang tumbuh pada permukaan medium SDA tampak berwarna putih kekuningan seperti kapas bertepung, koloni filamentous dan tepian koloni berbentuk filiform, terdapat garis-garis radial dan elevasi rata. Sebalik koloni berwarna kuning terang, berkerut dan terdapat lingkaran konsentris. Diameter pertumbuhan koloni $M$. canis pada medium SDA sebesar $6,5 \mathrm{~cm}$. Koloni pada medium PDA berwarna putih keabuabuan seperti tepung dengan elevasi berbentuk umbonate dan terdapat garis-garis radial. Sebalik koloni berwarna putih kekuningan dan terdapat lingkaran konsentris. Diameter pertumbuhan koloni $M$. canis pada medium PDA sebesar $4 \mathrm{~cm}$. Hasil pengamatan memperlihatkan, koloni $M$. canis yang tumbuh pada medium SDA tampak berwarna putih dan sebalik koloni berwarna kuning terang atau oranye. 
A.
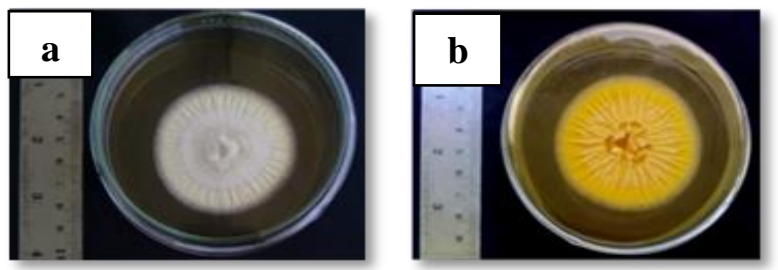

B.
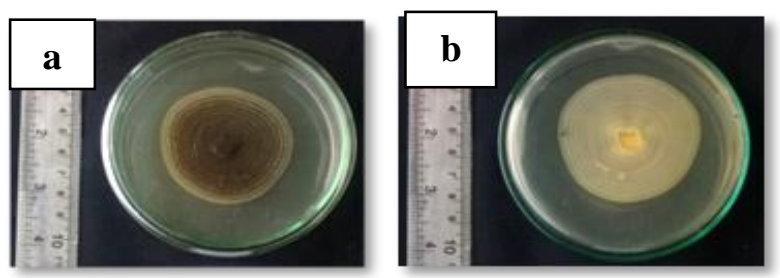

Gambar 2 Koloni M. canis A. Medium SDA inkubasi 5 hari (a) Permukaan Koloni berwarna putih (b) Sebalik Koloni berwarna kuning terang B. Medium PDA inkubasi 7 hari (a) Permukaan Koloni berwarna putih keabu-abuan (b) Sebalik Koloni berwarna putih kekuningan

\section{Pengaruh lama fermentasi terhadap pH medium kombucha teh hitam dan kombucha teh kulit manggis}

Hasil penelitian menunjukkan bahwa terjadi penurunan nilai $\mathrm{pH}$ selama fermentasi berlangsung terdapat pengaruh yang signifikan. Pengaruh lama fermentasi terhadap $\mathrm{pH}$ medium kombucha teh hitam dan kombucha teh kulit manggis dapat dilihat pada Gambar 3.

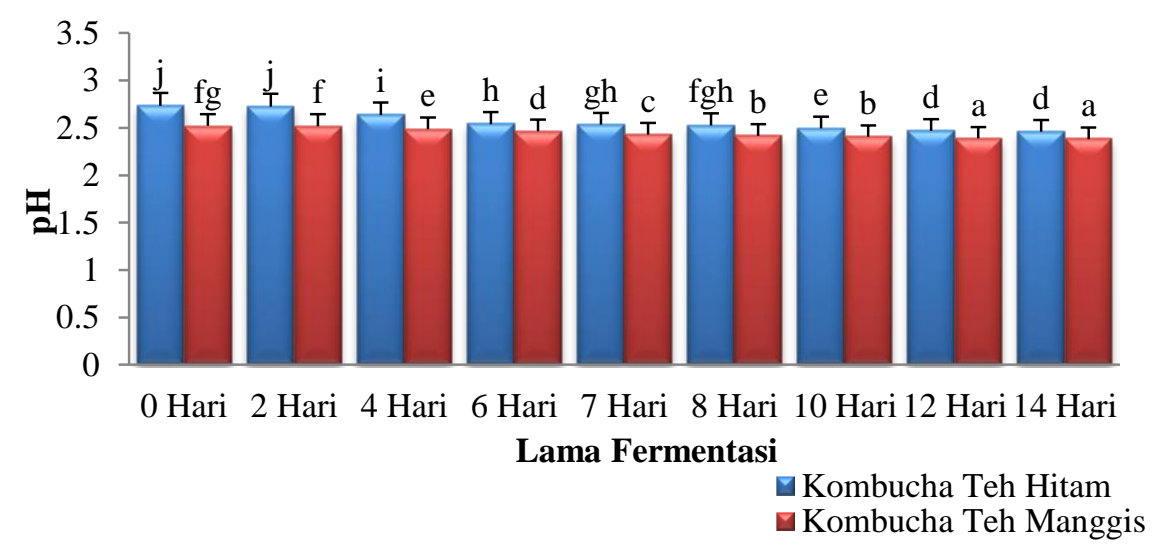

Gambar 3 Lama fermentasi terhadap $\mathrm{pH}$ medium kombucha teh hitam berbeda nyata dengan $\mathrm{pH}$ medium kombucha teh kulit manggis

Semakin lama fermentasi maka nilai $\mathrm{pH}$ akan semakin menurun. Lama fermentasi kombucha teh kulit manggis pada hari ke-14 merupakan nilai $\mathrm{pH}$ terendah sebesar 2,38. Penurunan $\mathrm{pH}$ terjadi secara berangsur-angsur, hal ini dikarenakan kadar sukrosa dalam media masih tersedia sehingga mikroorganisme di dalam media masih bisa melakukan metabolisme yang menyebabkan terbentuknya asam organik dan menyebabkan peningkatan total asam yang mengakibatkan penurunan nilai $\mathrm{pH}$.

\section{Aktivitas antibakteri kombucha teh hitam dan kombucha teh kulit manggis}

Pengaruh lama fermentasi terhadap aktivitas antibakteri kombucha teh hitam dan kombucha teh kulit manggis dalam menghambat pertumbuhan $S$. epidermidis dapat dilihat pada Gambar 4. 


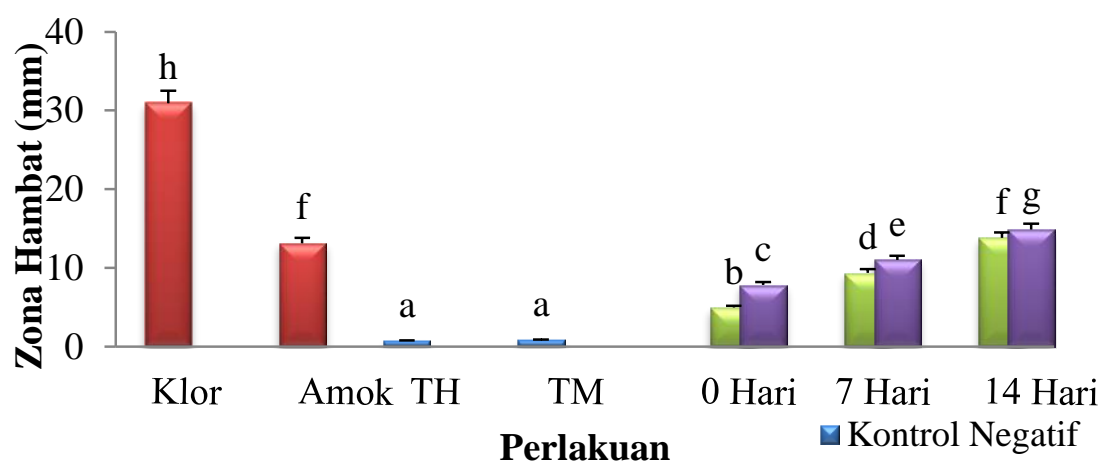

Gambar 4 a. Kontrol negatif teh hitam dan teh manggis tidak berbeda nyata b. Kontrol positif kloramfenikol paling besar menghambat pertumbuhan $S$. epidermidis pada semua perlakuan c. Fermentasi 14 hari mempunyai potensi paling besar dari 0 dan 7 hari. (Klor $=$ Kloramfenikol, Amok $=$ Amoksilin, $\mathrm{TH}=$ Teh Hitam. $\mathrm{TM}=\mathrm{Teh}$ Manggis)

Lama fermentasi berpengaruh nyata terhadap aktivitas antibakteri kombucha teh hitam dan kombucha teh kulit manggis dalam menghambat pertumbuhan S.epidermidis. Kombucha teh kulit manggis mempunyai potensi antibakteri yang lebih besar dengan rerata zona hambat sebesar 14,84 mm dibandingkan dengan kombucha teh hitam sebesar 13,81 mm. Kedua daya hambat ini termasuk kategori daerah hambat kuat (10-20 mm).

Aktivitas antibakteri kombucha teh hitam dan kombucha teh kulit manggis dalam menghambat pertumbuhan S. thyphimurium dapat dilihat pada Gambar 5.

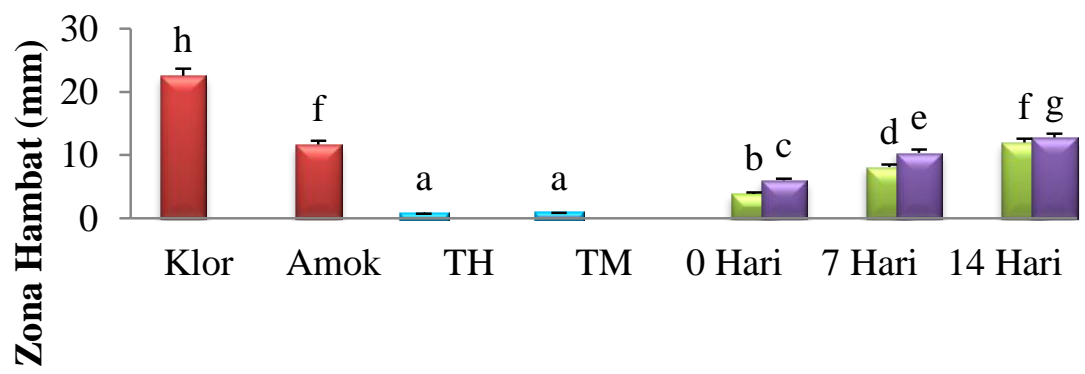

\section{Perlakuan}

Kontrol Negatif

Gambar 5 a. Kontrol negatif teh hitam dan teh manggis tidak berbeda nyata b. Kontrol positif kloramfenikol paling besar menghambat pertumbuhan $S$. thypi pada semua perlakuan c. Fermentasi 14 hari mempunyai potensi paling besar dari 0 dan 7 hari. $($ Klor $=$ Kloramfenikol, Amok $=$ Amoksilin, $\mathrm{TH}=$ Teh Hitam. TM $=$ Teh Manggis)

Aktivitas antibakteri kombucha terhadap S. thyphimurium yang paling terbesar terdapat pada kombucha teh kulit manggis fermentasi hari ke 14 dengan rata-rata zona hambat sebesar $12,77 \mathrm{~mm}$ dan kombucha teh hitam sebesar 12,00 mm yang termasuk kategori daerah hambat kuat (10-20 mm). Kontrol negatif teh tanpa perlakuan kombucha tidak berbeda nyata dengan nilai teh hitam sebesar $0,7 \mathrm{~mm}$ dan teh manggis sebesar $0,8 \mathrm{~mm}$. Kloramfenikol memiliki zona hambat paling tinggi yaitu rata-rata diameter sebesar 30,94 $\mathrm{mm}$. Zona hambat amoksilin tidak berbeda nyata terhadap kombucha teh hitam lama fermentasi 14 hari namun berbeda nyata dan lebih rendah dari kombucha teh kulit manggis lama fermentasi 14 hari. Rerata 
diameter zona hambat amoksilin terhadap kombucha teh hitam sebesar 13,14 mm yang termasuk pada kategori daya hambat resisten $(0-13 \mathrm{~mm})$.

\section{Aktivitas antijamur kombucha teh hitam dan kombucha teh kulit manggis terhadap Microsporum canis}

Uji aktivitas antijamur teh kombucha terhadap $M$. canis pada semua waktu fermentasi tidak dapat menghambat pertumbuhan $M$. canis. Namun antibiotik miconazol mampu menghambat pertumbuhan $M$. canis dengan zona hambat rerata sebesar $6,92 \mathrm{~mm}$. Zona hambat miconazol terhadap $M$. canis yang terbentuk termasuk kategori resisten $(\leq 11)$. Uji aktivitas antijamur terhadap pertumbuhan M. canis dapat terlihat pada Gambar 6

A

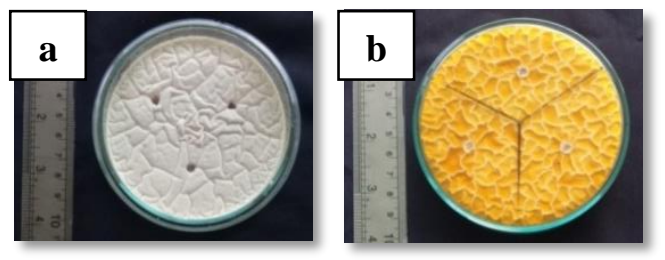

B

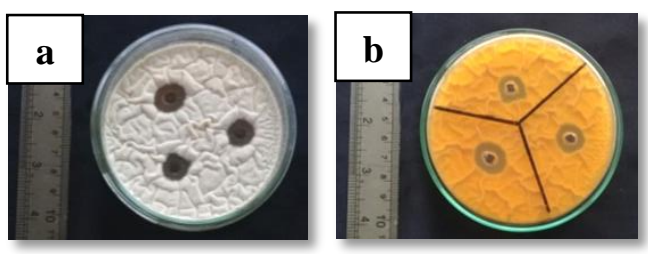

Gambar 6 Uji aktivitas antijamur terhadap pertumbuhan $M$. canis pada medium SDA inkubasi 3 hari. A. Kombucha teh kulit manggis fermentasi 14 hari (a) Permukaan koloni dan (b) Sebalik koloni B. Miconazol (a) Permukaan koloni dan (b) Sebalik koloni

\section{Pembahasan}

Penurunan nilai $\mathrm{pH}$ dapat disebabkan oleh bakteri dan khamir yang mengubah sukrosa menjadi asam organik selama fermentasi. Semakin lama fermentasi berlangsung maka aktivitas metabolisme mikroorganisme dalam memproduksi kadar asam semakin tinggi (Junior et al. 2009). Pengaruh lama fermentasi kombucha terhadap penurunan nilai $\mathrm{pH}$ sesuai dengan penelitian Ansari et al. (2017), bahwa lama fermentasi kombucha berpengaruh nyata terhadap penurunan nilai $\mathrm{pH}$ dari 2,72 pada hari 1 menjadi 2,09 pada hari ke 21. Mikrob dalam kombucha menghasilkan enzim yang dapat mengubah kandungan gula menjadi berbagai jenis asam. Wistiana (2015) menyatakan semakin lama fermentasi maka total gula akan semakin menurun, hal ini karenak gula digunakan sebagai substrat oleh kultur kombucha sehingga pada akhir fermentasi dihasilkan alkohol dan asam-asam organik seperti asam asetat, asam glukonat, dan asam glukoronat.

Perubahan nilai $\mathrm{pH}$ selama penyimpanan dapat menandakan adanya reaksi didalam media sehingga dapat menurunkan atau menaikkan nilai $\mathrm{pH}$, dimana perubahan nilai $\mathrm{pH}$ akan mempengaruhi efek yang diberikan oleh media tersebut ketika diaplikasikan. Hal ini sesuai dengan penelitian Putra et al. (2011) bahwa pH suatu media tergantung dari komponen penyusun baik zat aktif atau zat tambahan yang digunakan dalam formulasi. Kombucha teh kulit manggis memiliki nilai $\mathrm{pH}$ terendah, hal ini dikarenakan kandungan asam organik pada kulit manggis. Hal ini sesuai dengan penelitian Saraswati dan Suci (2011), pH teh manggis menurun seiring dengan lamanya waktu fermentasi. Selama fermentasi asam organik yang terbentuk akan mendenaturasi pigmen antosianin pada teh manggis yang menyebabkan $\mathrm{pH}$ semakin asam. 
Penambahan kombucha memberikan pengaruh yang signifikan terhadap besarnya zona hambat yang terbentuk, sehingga kombucha dengan kombinasi teh hitam dan teh manggis sangat berpotensi sebagai antibakteri. Menurut Hapsari (2008) kombucha mengandung berbagai jenis asam organik yang dihasilkan selama fermentasi berlangsung oleh mikroorganisme dalam kultur kombucha. Kandungan asam organik tersebut mampu menghambat pertumbuhan mikroorganisme lain selain dalam kultur kombucha. Penelitian Aditiwati dan Kusnadi (2003) menyatakan bahwa kadar asam pada kombucha mampu menghambat pertumbuhan bakteri patogen baik Gram positif maupun Gram negatif.

Penghambatan oleh kandungan kadar asam yang tinggi dari kombucha dapat disebabkan oleh penurunan nilai $\mathrm{pH}$. Nilai $\mathrm{pH}$ yang semakin asam seiring bertambahnya waktu fermentasi mampu menghambat pertumbuhan bakteri patogen. Uji aktivitas antibakteri menunjukkan bahwa kloramfenikol memiliki zona hambat paling tinggi. Hal ini menyatakan bahwa bakteri Gram positif dan Gram negatif yang digunakan dalam penelitian ini sensitif dan relatif masih cukup peka terhadap antibiotik Kloramfenikol. Menurut Nelwan (2002) sensitif disini dimaksudkan bahwa antibiotik memiliki kemampuan dalam menghambat pertumbuhan bakteri dengan spektrum zona hambat yang luas. Mekanisme kerja kloramfenikol yaitu dengan cara menghambat pembentukan sintesis protein sehingga dapat mengganggu metabolisme bakteri dan menyebabkan kematian pada bakteri. Salmonella thyphimurium dan S. epidermidis bersifat resisten terhadap Amoksilin. Proses resistensi disebabkan karena $S$. thyphimurium dan $S$. epidermidis dapat menghasilkan enzim $\beta$ laktamase. Enzim ini bertanggung jawab dalam peningkatan perlawanan terhadap amoksilin. Enzim $\beta$-laktamase melindungi bakteri Gram positif dan Gram negatif dengan cara menghancurkan antibiotika sebelum mencapai sel bakteri (Johnson \& Livermore 2001).

Daya hambat kombucha terhadap $S$. Epidermidis lebih besar dibandingkan dengan daya hambat terhadap $S$. thyphimurium. Hal tersebut disebabkan karena adanya perbedaan struktur dinding sel pada bakteri Gram Positif ( $S$. epidermidis) dengan bakteri Gram negatif ( $S$. thyphimurium). Struktur dinding sel bakteri Gram negatif lebih kompleks dibanding struktur dinding sel bakteri Gram positif (Siswandono \& Bambang 1995).

Meningkatnya konsentrasi asam pada lama fermentasi kombucha tidak mampu menghambat pertumbuhan $M$. canis. Kontrol positif miconazol mampu menghambat $M$. canis, namun berdasarkan kategori zona hambat $M$. canis telah resistensi terhadap miconazol. Resistensi kemungkinan terjadi karena penggunaan antibiotik tersebut telah banyak digunakan dalam dunia medis untuk pengobatan. Hal ini berdampak negatif yaitu fungi menjadi resisten terhadap antibiotik yang diberikan.Penelitian Pangesti (2014) menyatakan bahwa M.c anis merupakan jamur yang memiliki hifa dan septa lurus, memiliki banyak makrokonidia multiseluller dan berdinding tebal. Jamur yang memiliki dinding sel tebal akan menyulitkan senyawa antijamur untuk menembus dan menghambat pertumbuhan jamur tersebut.

Kontrol positif miconazol secara umum memiliki luas zona hambat terhadap $M$. canis, sedangkan kombucha teh hitam dan kombucha teh kulit manggis pada semua waktu inkubasi tidak mampu menghambat pertumbuhan M.canis. Hal ini disebabkan oleh kandungan zat anti jamur yang terkandung di dalam miconazol merupakan zat anti jamur yang sudah diproduksi secara komersial dan telah mengalami proses purifikasi (pemurnian zat aktif) sedangkan kombucha teh hitam dan kombucha teh kulit manggis belum dilakukan pemurnian zat aktif, sehingga zat antifungal yang terkandung di dalam kombucha teh hitam dan kombucha teh kulit manggis masih bercampur dengan zat aktif lainnya yang belum tentu bersifat anti jamur.

Berdasarkan hasil yang didapatkan dapat disimpulkan bahwa kombucha teh hitam dan kombucha teh kulit manggis berpotensi menghambat pertumbuhan $S$. epidermidis dan $S$. typhii, namun pada semua waktu inkubasi tidak mampu menghambat pertumbuhan M. canis. Kombucha teh hitam dan teh kulit manggis dengan lama fermentasi 14 hari merupakan 
fermentasi yang optimal dan memiliki potensi kategori daya hambat kuat terhadap pertumbuhan $S$. epidermidis dan $S$. typhi dengan rerata zona hambat sebesar $14.84 \mathrm{~mm}$ dan $12.77 \mathrm{~mm}$.

\section{Pustaka}

Aditiwati P, Kusnadi. 2003 - Kultur Campuran dan Faktor Lingkungan Mikroorganisme yang Berperan dalam Fermentasi "Tea-Cider". Jurnal Sains dan Teknologi 35 (2), 147159.

Amir RN, Shams GM, Ghajari A, Razzaghi M. 2006 - The Antifungal Effects of Griseofulvin and Terbinafine on Some Common Dermatophyte Species under In-Vitro Conditions. Hakim Research Journal 9 (1), 28-33.

Ansari F, Hadi P, Sahel E. 2017 - Study on Citric Acid Production and Antibacterial Activity of Kombucha Green Tea Beverage During Production and Storage. Annual Research and Review in Biology 16 (3), 1-8.

Battikh H, Bakhrouf A, Ammar E. 2012 - Antimicrobial Effect of Kombucha Analogues. Lebensm Wiss Technol. Journal food sci technol Kombucha 47 (1), 71-77.

CLSI. 2015. Performance Standards for Antimocrobial Susceptibility Testing. Twenty Second Informational Supplement 34 (1).

Christy AS. 2012 - Pengaruh Ekstrak Kulit Manggis (Garcinia Mangostana L) Terhadap Pertumbuhan Bakteri Vibrio cholera. Saintika Medika 8 (2), 97-102.

Darmadi. 2008 - The Antifungal Effects of Griseofulvin and Terbinafine on Some Common Dermatophyte Species under In-Vitro Conditions. Infeksi Nosokomial: Problematika dan Pengendaliannya. Jakarta: Salemba Medika.

Galih KP. 2015 - The Antifungal Effects of Griseofulvin and Terbinafine on Some Common Dermatophyte Species under In-Vitro Conditions. Antimicrobial Effectiveness Test Kombucha Easter lily (Lilium longiflorum Thunb.) In Addition Dates Extract (Phoenix dactilyfera L.) and Long Fermentation. UIN Maulana Malik Ibrahim, Malang

Gandotra S, Rahul KC, Shivani S. 2017 - Bioprospecting of Endophytic Actinomycetes from Plumbago Zeylanica for Antifungal Activity. World Journal of Pharmaceutical and Life Sciences 3, 263-268.

Jawetz E, Melnick J, Adelberg E. 1995 - Mikrobiologi Kedokteran. Edisi ke-20. EGC, Jakarta.

Jayabalan R, Phei-Ni C, Yih-Shou H, Prabhakaran K, Pitchai P, Marimuthu S, Thangaraj P, Swaminathan K, Yun SE. 2011 - Effect of Solvent Fraction of Kombucha Tea on Viability and Invasiveness of Cancer Cells-Characterization of Dimethy Malonet and Vitexin, Indian. Journal Biotechnol 10, 75-82.

Jayabalan R, Malbasa R, Loncar E, Vitas JS, Satish KM. 2014 - A Review on Kombucha Tea-Microbiology, Composition, Fermentation, Benefical Effects, Toxicity, and Tea Fungus. Comprehensive Reviews in Food Sciense and Food Safety 13, 538-550.

Jiang S, Nai-fang F, Zhi-chao D, Chang-hui L, Jun-cai W, Yan-yan Z, Yong-jin G, Jian-an L, Heng-qiu L, Dan-yu L, Jing-Xie, Xiao-jun L, Rui-hui P, Zuo-xing C, Lu-lu Z. 2017 Clearance of Free Silica in Rat Lungs by Spraying with Chinese Herbal Kombucha. Evidence-Based Complementary and Alternative Medicine, Volume 2013, Article ID 790792, 9 pages.

Junior RJ, Batista RA, Rodrigues SA, Filho LX, Lima AS. 2009 - Antimicrobial activity of broth fermented with kombucha colonies. Journal Microb Biochem Technology 1(1), $72-78$.

Lestari 1, Martina A, Yuharmen. 2016 - Uji Aktivitas Antifungal Ekstrak Kulit Buah Semangka (Citrullus vulgaris) dan Manggis (Garcinia mangostana L.) terhadap Jamur Penyebab Ketombe. Repository FMIPA, Universitas Riau, Riau. 
Loncar ES, Radomir V, Malbasa LA, Kolarov. 2007 - Kombucha Fermentation on Raw Extract of Different Cultivars of Jerusalem Artichoke. .Journal APTEFF 38, 37-44.

Mikaeil A, Masoud M, Siamand S, Isaac K. 2016 - The Antifungal Activities of Rosemary against Trichophyton tonsurans and Microsporum canis. International Journal of Pharmaceutical Research \& Allied Sciences 5(2), 472-483.

Ngan Donga N, Lea, Phu H. 2014 - Study on Antimicrobial and Antioxidant Activities Of Kombucha and Fermented Pineapple Juice. A thesis submitted to The School of Biotechnology. International University In partial Fulfillment of The Requirement For The Degree of B.S in Biotechnology.

Olosunde OF, Abu-Saeed K, Abu-Saeed MB. 20124 - Phytochemical Screening and Antimicrobial Properties of a Common Brand of Black Tea (Camellia sinensis) Marketed in Nigerian Environment. Adv Pharm Bull. 2(2), 259-263.

Pangesti Rida R. 2014 - Uji Daya Hambat Virgin Coconut Oil (VCO) Terhadap Pertumbuhan Kapang Microsporum canis Secara In Vitro. Skripsi. Bogor Agricultural University, Bogor.

Pourjafar H, Noori N, Gandomi H, Basti AA. 2016 - Study of Protective Role of Double Coated Beads of Calcium Alginate-Chitosaneudragit S100 Nanoparticles Achieved from Microencapsulation of Lactobacillus Acidophilus as a Predominant Flora of Human and Animals Gut. J Vet Res 71(3), 11-20.

Putra MM, Dewantara GNA Swastini DA. 2011 - Pengaruh Lama Penyimpanan Terhadap Nilai pH Sediaan Cold Cream Kombinasi Ekstrak Kulit Buah Manggis (Garcinia mangostana L.), Herba Pegagan (Centella asiatica) Dan Daun Gaharu (Gyrinops versteegii (Gilg) Domke).Jurnal Farmasi Udayana 3, 18-21.

Rinihapsari E, dan Richter CA. 2008 - Fermentasi Kombucha dan Potensinya Sebagai Minuman Kesehatan. Media Farnasi Indonesia 3 (2), 241-246.

Saraswati DN, Suci EA. 2011 - Ekstraksi dan Uji Stabilitas Zat Warna Alami dari Kulit Manggis. Universitas Diponegoro. http://eprints.undip.ac.id/36701/1/8.ARTIKEL_PENELITIAN_1.pdf

Siswandono dan Bambang S. 1995 - Kimia Medisinal. Surabaya: Erlangga

Yuniarto A, Kusnandar A, Riana ANA. 2016. Antifungal Activity of Kombucha Tea Against Human Pathogenic Fungi. Asian Journal of Pharmaceutical and Clinical Research 9, 253-255. 